\title{
Getting to the Roots: Constitutional Rules and the Zero-Sum Politics of Winner-Takes-All in Ghana
}

\author{
Michael Kpessa-Whyte ${ }^{1}$ Raymond A. Atuguba ${ }^{2}$ \\ 1.Senior Research Fellow, Institute of African Studies, University of Ghana, and former a Policy Advisor to the \\ President of the Republic of Ghana \\ 2.Dean of the Faculty of Law, University of Ghana, Legon, and former the Executive Secretary to the President \\ of the Republic of Ghana
}

\begin{abstract}
Ghana's democracy is plagued by zero-sum politics usually described as winner-takes-all. Winner-takes-all is political behaviour involving post-election distribution and redistribution of public resources to reward political loyalists, with or without considerations for competence and merit. A key mechanism for this is the appointment of such loyalists to public offices that control key national resources. Although winner-takes-all is seen as a cancer cell in the country's democracy and politics and has often been condemned by the citizenry and civil society organizations alike, it has become behaviour of choice for all political parties once they win the mandate to govern. This study analyses the institutional basis of contemporary democratic politics in Ghana, focusing on the rules, and argues that winner-takes-all is a rational response by political actors to the incentives and opportunities offered by specific formal and informal rules of the country's democracy. The argument is shaped by a careful analysis of specific legal provisions that incentivize political actors to act in that manner. The study makes two important contributions to our understanding of contemporary Ghanaians politics. First it provides an alternative perspective that suggests that winner-takes-all is an effect and not a cause of the country's governance challenges, and second it draws attention to the centrality of rules and their design in shaping political behaviour.
\end{abstract}

Keywords: Rules, Democracy, Winner-takes-all, Zero-sum, institutions, Ghana, Politics, Law

DOI: $10.7176 / \mathrm{JLPG} / 99-08$

Publication date:July $31^{\text {st }} 2020$

\section{Acknowledgement}

The authors appreciate financial support in the form of annual Book and Research Allowance (BRA) provided by the Government of Ghana.

\section{Introduction}

Since 1993 when Ghana returned to constitutional democracy, the country has witnessed three successful transfers of power from one political party to another. Specifically, power was transfer from the National Democratic Congress (NDC) to the New Patriotic Party (NPP) in 2001, then back to the NDC in 2009 and again to the NPP in 2017. While smooth transfer of power is a remarkable departure from the periods of political instability that defined the first three and half decades of the country's political development, the recent periods of democratic transfers of power have been characterized by the "politics of winner-takes-all" (Lindberg, 2003; Ijon, 2018; Abotsi, 2013; Kumah-Abiwu, 2017; Gyampo, 2015; Lamptey \& Salihu, 2012). This has reduced changes in government through competitive elections to the sharing of spoils usually associated with conquest in a war situation. President Jerry John Rawlings of the NDC, whose tenure established the 1992 constitution, was accused of appointing only NDC loyalists and persons from ethnic groups that supported his military regime and later political party to public offices (Gyimah-Boadi, 2003). In 2001, after President John Agyekum Kufour took office, he immediately proceeded to remove many actual or perceived loyalists of the NDC from public offices and replaced them with NPP loyalists. Although he was accused of not doing enough to exorcise his administration of appointees he inherited at his electoral victory in 2008 (Nkansah, 2012), appointments to various public offices made under Professor John Evans Atta Mills were largely shaped by affiliation, membership and sympathies to the NDC (Modernghana, 2009). President John Dramani Mahama who inherited the unexpired term of President Atta Mills maintained the appointments bequeathed to him, but signaled his desire to end the practice; and a preference for a more inclusive and merit-based distribution of appointments to political office (Mahama, 2012)). Thus, when he secured presidential victory in 2012, John Mahama made several high-profile appointments of persons who had no known partisan affiliation to the NDC at the time. This notwithstanding, he was also criticized not only by the NPP for what was described as appointment of family and friends, but also by the NDC for appointing persons with whom the party had no records of membership and affiliation. Following his electoral victory in the 2016 general elections, President Nana Akufo Addo appointed not only party loyalists of the NPP, but also many of his known friends and family to public offices (Graphic, 2019). 
This practice of sharing public offices and associated resources by successive presidents has received public condemnation from civil society organizations and citizens alike. For the most part, the public outcry stems from the manner in which public offices and state resources are captured and appropriated mostly by members of a victorious party after competitive elections. Thus, apprehension and concerns about winner-takes-all politics in Ghana have focused almost entirely on the dangers associated with the practice without regard for the root causes of the phenomenon; the rules of law and the ensuing institutional design that permit its persistence. For instance, there are media reports that three of the country's leading civil society organisations, the Institute of Democratic Governance (IDEG), the Institute of Economic Affairs, (IEA), and the Centre for Democracy and Development (CDD) converge on the view that the emergence of a two party system in Ghana has created a culture of sharing spoils and embeds politics of exclusion, marginalization, polarization, fear and panic, persistent threat of election violence, ensuring that a danger of instability persistently hangs over the country. They add that the practice tends to undermine socio-economic transformation of the country due to its acrimonious nature and the resulting animosity and hatred it fosters among political opponents (Ghanaweb, 2017; Ghana News Agency, 2014; Ghanaweb, 2018).

Ijon (2018) argues that the practice of winner takes all has its origins in the colonial administration which claimed everything in the then Gold Coast for the British crown, thereby not only depriving the indigenous population of everything, but also reducing them to slaves to be exploited. Consequently, the practice entered into postcolonial politics and shaped the relationship between the Convention Peoples Party (CPP) and the United Gold Coast Convention (UGCC) major political parties of the early postcolonial era. In reference to the situation since 1992, Justice Emile Short (2015) a former Commissioner for Human Rights and Administrative Justice (CHRAJ) in Ghana argues that the President's overriding powers in the appointment of heads of public institutions deepens the winner-takes-all phenomenon (Ghanaweb, 2017). Charles Gabriel Palmer-Buckle (2015), a leading cleric, warns that Ghana risks political stagnation if the winner-takes-all system is not effectively tackled (News Ghana, 2015). Expressing worry about the situation, one of Ghana's most astute and prominent statesmen, K.B. Asante (2016) in a feature article published in the national dailies averred that "it is wrong to give all official posts to party members whether competent or not. What I am strongly against is the term used to describe the system, namely winner-takes-all. A party wins an election alright, but the win is not like that of a lottery where chance selects the winner who takes all the money. We should completely reject any semblance of an election to a lotto. Political elections are serious undertakings of responsibility"

A few years earlier, a systematic, analytical, field-based and deep study of the operation of Ghana's 1992 Constitution (Kpessa \& Atuguba, 2013) found that "Ghanaians...prefer an inclusive government, as opposed to a winner-takes-all attitude". Views collected by the Constitution Review Commission across the country were to the effect that "there is the need to review the 'winner takes all' system in the nation's politics which hardly considers members of opposition parties as partners in development" because it "gives rise to corruption, bribery and violence in the country because political parties would want to use all means possible to win elections". These views are contained in a section of the report which summed up some radical views of a section of Ghanaians on winner-takes-all as follows:

"The introduction of partisan politics at the district level would ensure that political parties that lose national elections can still maintain control of some districts and stay relevant to the business of governing the nation, and extract benefits for their followers. This partisan presence can ultimately ameliorate, in a sobering way, the polarisation caused by the monopoly of a ruling party over both the central and local government structures in a 'winner-takes-all' system." (Commission Constitution Review, 2011, p. 741).

Indeed, in his first major policy statement upon assumption of office as interim President in July 2012, barely six months after this report was submitted, John Mahama expressed concerns about the pervasiveness of the politics of winner takes all in the country and pledged to ensure it is tackled (Mahama, 2012).

How do we explain the prevalence of winner-takes-all in Ghana irrespective of which political party governs? This paper seeks to answer this question through a discussion of the zero-sum politics of winner-takesall associated with contemporary Ghanaian democracy and argues that although the practice is an affront to the objectives of inclusivity and nation building, it nevertheless deprives its logic from specific rules of the country's democratic politics. Thus, contrary to perceptions that winner-takes-all is the cause of Ghana's governance challenges, the paper suggest that it is rather the effect of rules that define the character of the country's democracy. Winner takes-all should therefore be seen as a realistic and rational response to the incentives and opportunities offered by specific formal and informal rules of the country's democratic system. This framing of the argument is not intended in any way to defend or justify the practice; rather, it presents alternative perspectives that allow for policy makers and the citizenry alike to identify rules that provide incentives to embolden the practice and engender appropriate reforms. This argument is interesting because it departs from the existing explanations that seek to portray winner-takes-all as deviant political behaviour and second, it draws attention to the importance of rules in shaping the political behaviour of actors. 
The rest of the paper is divided into three sections. While the first section discusses the conceptual home of the politics of winner-takes-all, situating it within the broader notion of neo-patrimonial politics, the second section identifies and explains the role of specific rules governing Ghana's democratic politics in directly or indirectly incentivizing the phenomenon. The concluding section draws lessons from the analyses for improving our understanding of political behaviours associated with winner-takes-all politics. Methodologically, the paper draws on analysis of some existing legislative frameworks, observations, and the review of newspaper reports and secondary literature.

\section{Politics of Winner-Takes-All in Perspective}

Winner-takes-all is a form of political patronage in which democratically elected office-holders restrict recruitment to public office, often carried out through the power of appointment vested in them, mostly to individuals with whom the office-holders shares similar political beliefs or affiliations or to party loyalists. In other words, it is a political arrangement in which a political party or its candidate, after winning an election and taking control of the state machinery, gives most or all government jobs to its supporters, friends and relatives as a reward for their support and contributions for the victory, and as an enticement for them to continue working for the party and candidate for the purposes of future elections. Often, such appointments are preceded by a mass removal from office of existing staff in various positions in the public services. The practice is akin to what has been described as patrimonial politics in which political authority is exercised on the basis of relationships of personal loyalty between the individual who possesses the mandate to govern and the administrative staff (Weber, 1947). According to Kelsall (2011) although Weber's analysis observed that patrimonialism takes various forms, in all its variants, it points to a "political system held together by personal distribution of material resources and perks" deliberately given out in a manner that creates the impression that resources distributed emanate from the personal benevolence and magnanimity of persons in position of authority. In such a political system, the lines between that which is public and that which is private are blurred at best, and the leader enjoys absolute power by engendering support through the distribution of state resources guised as private property.

Following the logic of Weber, politics in African countries have been described in various ways, primarily on accounts of what is considered a misfit between political behaviour found on the continent and ideas of Weber. Thus, attempts to understand the nature and dynamics of the relationship between governments and the governed has found expression in multiplicity of terminologies. For O'Donnell, (1996) politics in Ghana and African countries can best be described as acts of clientelism. Bayart (1993) described the same situation as politics of the belly, and Chabal and Daloz (1999) described it as the instrumentalization of informal politics. Joseph (1987) used the term prebendalisms, and Sandbrook (1985) neo-patrimonialism. Although these and other scholars differed in the specific lexiconic label of the phenomenon studied, there is general convergence among them suggesting that African politics is characterized by a co-existence of formal and informal institutions of governance, with the latter often serving as the key point of reference for what is considered appropriate behaviour as far as the relationship between political leaders and their followers is concerned. As such African democracies are seen as manifesting systems in which political relationships that are broadly patrimonial in nature pervade and supplant legal-rational administrative arrangements (Clapham, 1985)). As a result, leaders occupy positions of power in the formal-legal sense but exercise that power not in the formal-legal sense. Rather, such power is considered personal property and thus used to secure support and loyalty from sections of the population.

In a study that focused on Southeast Asia, Scott (1972) noted that countries where colonial political institutions are superimposed on indigenous systems of governance, the relationship between leaders and their followers is shaped by the norms of patron-client principles, where the leaders (patrons) by virtue of access to resources made available by the position of power, are able to buy the loyalty and support of others (clients) in a manner that suggests that resources of the position are personal properties and only enjoyed by the clients at the goodwill and benevolence of the patrons. In particular, the relationship is shaped by the values of reciprocity in which the leader offers favors and access to resources associated with the position to the clients, and in turn secures the loyalty and support of those clients in the performance of the duties and responsibilities associated with that position. In one study, Van de Walle, (2001) argued that "political authority in Africa is based on the giving and granting of favors, in an endless series of dyadic exchanges that go from the village level to the highest reaches of the central state" (p. 51), and politics is essentially about "providing material resources in exchange for personal loyalty" (Lindberg, 2003, pp. 123-4). Chabal \& Daloz (1999) attribute the prevalence of patron-client behaviour in African politics to the primacy of ethnicity in which the position of power is highly valued due to its ability to engineer access to resources for the benefit or support of one's family and kinsmen and as well reinforce loyalty and solidarity. According to Van de Welle, (2007) patron-client politics is often characterized by patronage, which is a phenomenon ubiquitous with mass politics, and defined as the "practice of using state resources to provide jobs and services for political clienteles" with the sole purpose of generating support for the patron, as well as, prebendalisms, which involves offering an individual a position in "public 
office in order for him/her to gain personal access over state resources" (p 51).

The practice of rewarding loyal support with positions in public office in democratic politics is traced to several early America Presidents, however it was not until Andrew Jackson, that what became known as the spoils system was officially made a government policy (Fish, 1905; Friedrich, 1937). Upon assumption of office in March 1829 as President after a bitter campaign, Andrew Jackson grew suspicious of the staff of the federal public service who had worked with his predecessor, and thought their continuous stay would undermine his administration's programs. Angered that people in the federal service who were opposed to him consistently blocked some of his initiatives, Jackson came up with a plan to cleanse the service of potential political opponents and replace them with persons whose loyalty he could count on (Somit, 1984). Although Jackson's political opponents resisted his policy of packing the public service with members of his political establishment, he prevailed, and according to McNamara (2020) government records of the 19th century show "that Jackson's policy accounted for nearly 700 government officers losing their jobs in 1829, the first year of his presidency. In July 1829 , there was a newspaper report claiming the mass firings of federal employees actually affected the economy of the city of Washington, with merchants unable to sell goods".

Jackson and his supporters were accused of abusing power to corrupt the federal public service, but in a statement credited to one of Jackson's loyalists, they defended the practice of appointing party supporters to public office by arguing that "They see nothing wrong in the rule that to the victors belong the spoils" (Hofstadter, 1970, p. 250). This policy was further defended by Jackson himself in a statement noting "in a country where offices are created solely for the benefit of the people no man has any more intrinsic right to official station than another. Offices were not established to give support to particular men at the public expense. No individual wrong is therefore, done by removal, since neither appointment to nor continuance in office is a matter of right" (Jackson, 1829). Bearfield (2009) noted that Jackson's very rise to the presidency was shaped by campaigns "promising state and local politicians control over patronage appointments in exchange for their support" (p. 69). Jackson's spoils politics shares striking similarity with the phenomenon of winner-takes-all in contemporary democratic politics. Indeed, winner-takes-all is a reflection of modern competitive politics, which divides societies on the basis of ideology, class, ethnicity or other forms of identity.

\section{Understanding the Role of Rules in Political Behaviour}

The study of rules in the social sciences has primarily been the preoccupation of economists, political scientists, and sociologist for a long time especially in works committed to institutional theory and governance. In its earliest form, institutional analysis in the social sciences was normative in character and committed to understanding how to design appropriate political institutions and systems that would serve the common good of society. Writing after the English Civil War, Thomas Hobbes advocated for the development of strong political institutions to save mankind from his worst self. John Locke on the other hand, argued for the contractual design of political institutions to ensure that politics and governance prioritizes things that matter most to the people in society. Indeed, the works of Rousseau, Montesquieu, and several other political philosophers share common interest in the structural design of political institutions. In this early tradition of scholarship, institutional analysis was confined to the study of formal aspects of the machinery of government including the making of laws, the operations of the executive, legislature and judiciary, among others. For the most part, institutional analysis of this period was heavily descriptive and normative in character.

Following the works of March \& Olsen (1984) that drew attention to the centrality of values and norms in shaping human behaviour and decisions made by political actors, institutional analysis broadened its scope to accommodate a wide variety of issues that shape collective decisions, especially in politics. In particular, institutions were seen not only as "rules of the game" (North, 1990) and the "foundation of life" but also defined to include "the formal and informal rules, monitoring and enforcement mechanisms, and systems of meaning that define the context within which individuals, corporations, labor unions, nation-states and other organizations operate and interact with each other. They are settlements born from struggles and bargaining" (Campbell, 2004, p. 1). This perspective is widely shared by several scholars in the social sciences engaged in institutional analysis. While Hall (1986) noted that institutions are "the formal rules, compliance procedures, and standards operating practices that structure the relationship between individuals in various units of the polity and economy" (p. 19); Krasner (1982) described institutions as consisting of principles, rules, norms, and shared expectations that serve as the reference point that filters the expectations of actors.

In another work much later, Hall \& Taylor (1996) noted that institutions include not only the formal and informal rules, but also "routines, norms and conventions embedded" in organizational structure, and these range from accepted operating procedures in administrative establishments to "conventions governing trade unions behavior or bank-firm relations" (p. 938). North (1990) whose institutional analysis won him the Nobel Prize in Economics, also defined institutions as "any form of constraints that human beings devise to share interaction" or as regularities in competitive interactions...customs, and rules that provide a set of incentives and disincentives for individuals" (p. 4). Although the above definitions and descriptions of institutions are drawn 
largely from political scientists, sociologists, and economists, there is a general consensus, the disciplinary differences notwithstanding, that institutions are ubiquitous in the daily lives of human beings and consist of a wide array of standards including routine procedures, customs, conventions, and widely accepted operating norms that may or may not necessarily be formally codified, but directly or indirectly serve as reference points for human action in a given context; and being reference points for social and political action, institutions provide both incentives and constraints that shape the conduct of individuals and organizations.

As Peters (1999) observes, even though scholars differ significantly in terms of their areas of emphasis, there is a broad convergence on the view that human action including political "behaviours are a function of rules and incentives" (p. 19). Social Scientists studying institutions are grouped into three broad categories consisting of historical institutionalists, sociological institutionalists, and rational choice institutionalists, reflecting primarily the conceptual and methodological biases of political science, sociology and economics respectively. While most historical institutionalists and rational choice institutionalists limit their view of institutions primarily to formal and informal rules, sociological institutionalist take a broader view of institutions to include the "taken-for-granted cultural frameworks, cognitive schema and routinized processes of reproduction" (Campbell, 2004, p. 11); and "symbol systems, cognitive scripts and moral templates that provide the frame of meaning guiding human action" (Hall \& Taylor, 1996, p. 947). Formal rules consist of Constitutions; Acts of Parliament; Constitutional, Legislative and Executive Instruments; Regulations; Bylaws; and Codes of Conduct among others. Informal rules on the other hand, include social norms, conventions, customs, principled belief, and generalized expectations.

All the three schools of institutional theory share the view that rules are always implicitly or explicitly the reference points for human behaviour, and thus actors are guided by what both sociological and historical institutionalists described as "logic of appropriateness" and rational choice as "logic of instrumentality" (Campbell, 2004). So, in the political world for instance, politicians usually would scan through their institutional environment to ensure that their decisions and actions are in conformity with the generally accepted forms of behaviour and provide the maximum benefit to the society. As Peters (1999) argues, if a rule is effective in shaping the behaviour of actors, those actors usually will spend some time to reflect on whether their actions and decisions are in conformity with the values and norms of their society or organization. From an institutionalist point of view therefore, rules possess compelling authority and legitimacy that commit human beings to behave in a manner that is generally consistent with the expected behaviour embedded in them, even if those behaviours violate the preferences and interests of the said human beings.

The thrust of institutionalists' argument is that the human world is wired by rules, and those rules are instrumental in shaping and structuring behaviour. March \& Olsen (1995) as quoted in Goodin, Jones, Simon (1999) argued that "political actors act and organize themselves in accordance with rules and practices that are socially constructed, publicly known, anticipated and accepted"....... and the "rules and understandings frame thought, shape behavior and constrain interpretation" (p. 73). Irrespective of the disciplinary differences, institutionalists are unanimous in the view that rules provide the toolkits from which actors interpret their social, political and economic situations, and determine what constitutes appropriate behaviour. Rules do not only possess inherent values that motivate or encourage human behaviour in some directions, they also make the doing of some things possible and desirable, and others not. In addition, rules impose limitations on what human beings as social, economic and political agents can do and cannot do, and they are usually embedded with penalties or incentives that a person might suffer or enjoy as a consequence of behaving in a manner considered inconsistent or consistent with a given rule. Rules are also noted for helping to create order through the provision of organizing principles and definitions of what constitutes acceptable behaviour. They generate their own expectations and consciously and unconsciously lie at the foreground of human action.

Consequently, what an actor considers appropriate human behaviour derives its logic of appropriateness from existing rules of a given context. In shaping human behaviour, rules tend to not only specify what an actor should do, but also what one can imagine oneself doing in a given situation. In addition, because they provide the cognitive scripts through which actors' orientations and preferences are filtered, they shape not only the strategic calculus but also the preferences and identities of actors (Campbell, 2004). Ostrom (1986) argues that rules are meant to achieve "order and predictability" by creating positions, indicating how actors enter and exit from those positions, specifying which actions the actors in those positions are "required, permitted, or forbidden to take" as well as the outcomes that the actors are permitted or prohibited to effect (p. 5). Rules therefore prescribe appropriate behaviour by telling actors where to look for appropriate actions, and thus facilitate interpretation of ambivalent situations. Understanding the institutional, that is the formal and informal rules that shape the behaviour of political actors in contemporary Ghanaian democratic politics is a major first step to appreciating the roots of the country's politics of winner-takes-all.

\section{Rules Incentivizing Ghana's Politics of Winner-Takes-All}

The exogenous origins of modern Ghana as an amalgam of several indigenous ethnic nations meant that the 
crafting of a constitution to hold the Republic together pays attention to rules that promote an inclusive state (Anyimadu, 1997). Ghana's 1992 Constitution undoubtedly gave due cognizance to the importance of national unity by prohibiting the formation of political parties along ethnic or religious lines, and also enjoins elected presidents to ensure appointments to public offices take account of regional and gender balance. However, a number of rules that foreground the county's democracy also provide tremendous incentives for elected presidents to make appointments to public officers in a manner consistent with the politics of winner-takes-all, without necessarily compromising the requirement of regional and gender balance imposed on such appointments.

Indeed, by the very nature of competition-based democratic politics that is based on competitive partisan elections, it is expected that every electoral victory would bring along opportunities for the victor to make appointments for public office. For most political parties, once an electoral victory is secured, the task of executing the mandate given by the electorates requires making appointments to other public offices. Such appointments present an opportunity to select persons who are trusted and loyal. Modern democratic politics is an enterprise founded on trust, and just as the electorate in exercising their franchise demonstrate which political party or candidate should hold their trust, so too is trust critical for elected leaders in choosing who can assist them in the delivery of their vision and mandate. Unfortunately, comparative political literature is thick on trust as the basis of democratic politics but thin on trust as the foundation of the power of appointments vested in elected leaders. Beyond trust, it stands to reason that because leaders are presumably elected on the basis of a vision, the choice of persons for appointment to offices that participate in the execution of that vision would be based on their belief in the basic tenets of the vision; and demonstrated loyalty to the vision exhibited through participation in processes that led to its framing, articulation, and acceptance by the general public.

No democracy can survive without the loyalty of the citizenry to democratic principles and procedures such as tolerance, compromise, and due process. This logic can be extended and arguably hold true for those to whom popular sovereignty of the people are entrusted. It may prove suicidal for an elected president to appoint persons whose loyalty to the vision that bore their mandate is suspect. Thus, concerns over loyalty and trustworthiness have compelled elected presidents in environments of competitive politics to err on the side of caution by sharing public office appointments among persons from their own political fraternity, thereby reducing democracy to a zero-sum game. This is what animates Gyampo's (2015) description of the politics of winner-takes-all in Ghana as "the partisan monopolization of state resources, facilities, and opportunities, as well as the exclusion of political opponents from national governance" (p. 17). Although this view captures the practice as deployed, it ignores the fact that in winner-takes-all environments, political actors do not compete for power in order to share it with their opponents or with persons whose commitment and loyalty to their belief system and worldview is unknown. By design political parties or candidates in an election compete on the basis of differences in worldviews about what constitutes problems of society and the best strategies to resolve them. It is therefore expected that once power is won, the victor will jealously guard it, and in sharing it, appreciation and recognition are given to persons who share in the broader vision upon which the victory is secured. This is shaped by the fact that in most competitive political environments, electoral politics is treated as an art of warfare, sometimes complete with bloody violence.

Consequently, electoral victory is equated to conquest as it happens in actual warfare, and state resources become booties of war to be shared among the members of the victorious party as rewards, and to encourage them to support similar efforts in the future. Thus, although campaigns for election by political parties and their candidates in winners-takes-all political environments also follow appeals to the generality of the populace, after victory is secured, the discernible behaviours associated with winner-takes-all begin to surface. Typically, such behaviours include removal of perceived political opponents from office regardless of merit and competence, sharing political offices for and among party loyalists, appointment of unqualified party supporters to public office as rewards for support, and treatment of state resources as war booties to be shared among party apparatchiks. Even though the practice is against the objective of nation-building and political inclusion due to its sometimes wasteful, discriminatory, divisive, and exclusionary nature, it persists. This is because such actions derive their logic of appropriateness from the institutional rules that underpin the competitive elections from which governments are produced. While such behaviours may be seen as infractions on commonsense, they remain unconstrained by widely shared norms and expectations.

In addition, it is generally accepted that individuals and groups directly or indirectly contribute to the election of a party or candidate to form a government because of a shared ideological worldview, but more important because they expect their efforts to be appropriately rewarded. For candidates and political parties, such rewards when granted, are demonstrations of trust and believability, and become political currency to purchase loyal and support towards the next election. Thus, in winner-takes-all politics, candidates of a political party who chooses to dabble in "father for all" or "mother for all" politics by appointing to public office persons unknown to their political party after victory is secured, risks losing the support of the rank and file of their party, irrespective of whether such appointments were made on the basis of competence or merit. This is so, because, it 
is in the nature of winner-takes-all politics not to share the "spoils" with anyone other than the victors. It must however be understood that democracy is an idea, an ideal, the practice of which requires wise institutional engineering, in part through the design and deployment of rules that weaken and constrain the human tendency to use political power primarily for selfish ends, including the temptation to engage in spoils-sharing in the form of allocating state resources for the purposes of winning and sustaining political loyalty. The ability of a democracy to promote inclusiveness or conversely divide a people along class, ethnic, racial, religious or other lines is partly a function of the rules that lie at the foundation of its establishment. This underscores the importance of rules in shaping the behaviour of political actors.

It therefore goes without saying that there are taken-for-granted informal rules inherent in the institutional design of Ghana's democracy that encourage the behaviour of winner takes-all on the part of elected officials. For instance, the very choice of competition as the mechanism through which political leaders are chosen has the tendency to produce an environment in which winners in a political competition will treat their victory as an opportunity for spoils sharing. Political competition theorists argue that electoral competition creates an incentive for incumbent leaders to govern well given that the electorate generally punish nonperformance with rejection. This principle in turn creates incentives for organized political opposition to present alternative policies and programs to the public with the view of being rewarded with the trust of the people in an electoral competition. According to this school of thought, the process helps to ensure accountability, also improves the substantive quality of government output, and promotes healthy political discourse especially because organized political parties seek to outshine one another in the market place of policy ideas (Downs, 1957).

However, the experience in Ghana and in other democracies suggest that political competition can be very divisive and descend into an exercise of slandering political opponents. Ghana's competitive political environment is akin to war among various groups. Campaigns are waged and pursued as though the parties are at war with each other. In such a political environment, politics is treated like war, and political opponents are not seen as collaborators in the struggle to provide public goods, but as adversaries or enemies that must be vanquished, crushed and eliminated. It is this poisoned environment of electoral competition that emboldens elected leaders to distribute resources associated with public office in a manner akin to spoilt-sharing after war. The unspoken view of competitive elections in Ghana as war by other means, means that sharing of the spoils after the elections are over derives its logic of appropriateness from the very divisive and "we versus them" nature of the country's system of competitive electoral competition.

Pushing the war analogy further, there is a generally accepted mechanism where elections are fueled by real and immediate rewards or promises of rewards in the future. The artillery for the electoral war is, therefore, cash, now or later, and actual electioneering campaigns are designed in a monied fashion. A convoy of fuel guzzling four-wheel drive cars carry candidates and their loyalists and trekking from one end of the country to the other, dishing out cash and gifts while promising everything from skyscrapers to pit latrines. Aping the older democracies, media advertisements are taken out for cash or on credit, and various organisations spring up and undertake thousands of events and initiatives in support of the candidate, usually ending with food and refreshments that cost lots of money. Many rural dwellers, illegitimately starved of central government and city resources, wait patiently every four years for this day to dawn, so that they may exploit the candidate and her loyalties and stock enough resources for the ensuing four years. Candidates for political office pre-finance all these activities with loans and donations from where-ever they can find them. Heavily indebted after victory, the rationale course of action is to pay off debts and reward loyalty through the spoils of electoral victory.

Third, the lack of direct state funding of political parties has incentivized the use of appointments to political office as reward for those whose financial and other contributions produce the victory in elections. Since 1992, all elected presidents ran and won their elections on the ticket of political parties, and the largest majority of Members of Parliament have also earned their place in the legislature through their political parties. Given the importance of political parties in our democracy, it is puzzling that the state does not provide public funding for political parties. Political parties today are not only instruments for interest aggregation and articulation, they are also the only organizations that provide form and meaning to elections in our democracy. However, the closest the 1992 Constitution comes to matters of funding of political parties is the provision in Article 55 (15), which states that "only a citizen of Ghana can make contribution or donation to a political party registered in Ghana." This provision was given some flesh by the Political Parties Act, 2000 (Act 574) which limits funding of political parties in Ghana to donations and financial contributions from Ghanaians and entities of Ghanaian ownership.

Arguably, the intention of the framers of the 1992 Constitution from which the Political Parties Act derived its strength is to ensure that the citizens through their voluntary contributions and active membership will own and control the activities of political parties including their programs and choice of candidates. What is lost on the framers is that in environments of radical poverty, where only very few have disposable income and where workers live from pay cheque to pay cheque, and a large majority of non-salaried workers have no sustainable means of livelihood, the noble idea of voluntary financial contribution to political parties is a distant dream. The 
absence of direct state funding of political parties has, therefore, created a situation where elected leaders use positions of public office or public resources to reward or show appreciation to individuals whose financial support contribute to their electoral victory. Unsurprisingly, persons who make financial and other contributions to the election efforts of parties and candidates perceive their efforts as investments, expecting to be rewarded generously once victory is achieved and the candidate so supported assumes political office. Thus, the lack of state funding of political activities has created incentives for elected leaders to treat the mandate obtained through competitive elections as spoils of war to be shared among the troops they commanded in the battlefield. In such situations, elected leaders are tempted to distribute public office appointments to friends, family, party supporters, and close acquaintances not necessarily on merit but mostly on the grounds of their past loyalty and support as well as expected future loyalty and support.

Fourth, the provisions in the Constitution that grant elected presidents the opportunity to contest for reelection for a second four-year term incentivizes incumbent leaders to act in a manner that rewards party members and supporters as a way of encouraging them to work toward a re-election bid. Although the idea of reelection is a mechanism intended to induce accountability and responsiveness of governments (Carey, 2013), it has also been instrumental in fostering an environment of perpetual partisanship, as the ruling party and the opposition parties persistently struggle to undo each other in the public space. Advocates of presidential reelection contend that "the possibility of re-election increases a politician's responsiveness to citizen demands and allows voters the freedom to retain popular incumbents" (Carey, 2013, p. 119). In addition, re-election is perceived as a measure that can compel incumbent presidents to act in a responsible and accountable manner by aligning their policies and programs to the needs, expectations and aspirations of voters. This is based on the belief that voters will "reward politicians who promise and deliver popular policies, such that such presidents who aspire to re-election will be more attentive to citizens' preferences than those who are constitutional lame ducks" (Carey, 2013, p. 126). Undoubtedly, the thinking behind re-election ensures that voters have the opportunity to assess the quality of leadership offered by an elected president and reward or punish them depending on the outcome of their assessments. To that extent, therefore, presidents are constantly reminded on the verdict that awaits them in re-elections. Even though fundamentally re-election was espoused on the believe that it will induce high performance by incumbents, it has, for presidents serving their first term, made elections always loom large in their scheme of things, more as a threat than as a source of empowerment or encouragement.

In relation to the above, the experience in Ghana since 1993 suggests that presidents serving their first term have always had to perceive and deal with the next election as a danger, and the entirety of governance processes is filtered through what can deliver the next election. But pondering about the next election goes beyond mere performance, especially in contexts where political opponents in the spirit of campaigns make every effort to discredit even the most notable achievements. Taken together, the situation compels the elected presidents in Ghana not only to begin thinking about the next election by way of their re-election and to safeguard their chances, but to take the logical step to share public offices and resources to individuals who contributed to their electoral victory in the first instance; or to those who belong to their parties as a reward for previous support, and as a form of insurance premium for expected support in the next election. Thus, the insertion of re-election as an accountability measure in Ghana's electoral system, is an institutional rule that weakens the incentives for appointments based on meritocracy, and instead enhances the opportunity structures for leaders to act in a manner that reflects winner-takes-all.

Finally, the President's wide powers of appointment as provided for in the 1992 Constitution and the Presidential Transition Act have together created a fertile ground for the politics of winner-takes-all. The practice during transfers of power since 2000 has been that the outgoing president retires with almost all the appointees who worked during the term of that president in various capacities. This convention was given formal legal backing in 2012 with the passage of the Presidential Transition Act which states in section 14 that

"(1) On the assumption of office of the person elected as President, a person holding any of the offices specified in the Schedule shall cease to hold that office, and shall be paid the relevant retirement benefits and the enjoyment of facilities as provided by law.

(2) The functions of office of a person who ceases to hold office under subsection (1) shall be performed by a person so appointed by the President for the period specified in writing by the President."

The Schedule in reference states that the following office holders cease to be occupiers of their respective offices upon the assumption of power by a newly elected president. They include (a) Ministers and Deputy Ministers of State, (b) Regional and Deputy Regional Ministers of State, (c) Special Assistants, Special Aides to the President, to the Vice-President and to the Ministers of State, Deputy Ministers, Regional Ministers and Deputy Regional Ministers, (d) Non-career Ambassadors and High Commissioners, and (e) Persons appointed by the President or a Minister of State as members of Statutory Boards and Corporations. In effect, these provisions made it mandatory for all these persons appointed by an outgoing president to vacate their offices 
and make way for the incoming president and his team. With various public offices rendered vacant once a new president assumes office, the door is opened for a new president to make appointments to positions as deemed necessary for the performance of the duties assigned the office.

The presidential power of appointment derives its logic of appropriateness from several provisions in the 1992 Constitution, and has been a recipe for the politics of winner-takes-all. For instance, Article 70 (1) (a-e); Article 74 (1); Article 86 (2) (i); Article 183(4) (a); Article 185(3); Article 189 (1) (a); Article 70 (2); Article 232 (2); Article 78(1); Article 79 (1); Article 144 (1-5); Article 86(2) (vi); Article 89 (2) (a) (i-iii); Article 89 (2) (d); Article 153 (n); and Article 166(1)(c) all grant a president various degrees of powers to appointment persons to positions ranging from Ministers and Deputy Ministers of State, some members of the Council of State, noncareer ambassadors, members of the National Development Planning Commission, Governor of the Central Bank, Administrator of the District Assembly Common Fund, and the members of the Public Services Commission. In addition, the president has the power to appoint a Chief Justice, an Auditor-General, and Commissioners of the Electoral Commission, the Commission on Human Rights and Administrative Justice and the National Commission on Civic Education when such positions are vacant. Furthermore, an elected president is also clothed with powers to nominate others, including District, Municipal and Metropolitan Chief Executives for approval by the assemblies, and appoint members of hundreds of statutory boards under the ministries, departments and agencies across the country. It therefore stands to reason that the provisions in the constitution and other legislation requiring an outgoing president to exit together with his or her appointees, while granting an incoming president extensive powers of appointment, are in themselves constitutional and lawful foundations for what has now become the politics of winner-takes-all in Ghana.

\section{Conclusion}

For multi-ethnic post-colonial states in Africa that take the attainment of independence also as the birth of a new social contract, the primary objective of the polity is to (a) build a new sense of nationhood, (c) promote socioeconomic development, and (c) establish democratic systems of governance. The challenges presented by institutional design for governance processes and nation-building in Ghana raises questions about the overall sync between rules of governance and the quest for building an inclusive nation-state. Prior to colonial rule, Ghana like most African countries adopted democratic institutions in different variations that prioritize consensus-building, collaboration, and cooperation among different factions and groups in society. The ruthless manner in which colonial rule superimpose western institutions of governance on preexisting rules has resulted in a bifurcation of the public space. With this context in mind, the design of democratic institutions in Ghana ought to have taken into account the primacy of rules that have the tendency to pull the people together, rather than those that push them apart. The preference for a partisan competitive mode of electing national leaders in the manner in which it was design has largely been responsible for the challenge of winner-takes-all, which is arguably the number one bane of Ghana's democratic experiment. This is because the practice ties in well with other nefarious practices such as monied democracy, the militarization of political parties, political vigilantism, ethnicity, opportunity hoarding, and many other related practices.

Although the political parties and civil society organizations have expressed worry about the exclusionary character of winner-takes-all politics in Ghana it remains the behaviour of choice for political parties when they are elected to office. In this paper, we have argued that winner-takes-all is an effect and not a cause of the country's governance challenges. This is because, it is the institutional design of our democratic experiment, which is a function of our rules of governance, that accounts for the winner-takes-all phenomenon. In this way, we draw attention to the centrality of formal and informal rules and their design in shaping political behaviour.

By examining various provisions of Ghana's Constitution and key Acts of Parliament that regulate competition for political office, we isolate the following as the culprits that engender the winner-takes-all phenomenon. First are the rules that institute competitive electoral politics; then the rules that allow money electioneering; third are the rules that sustain the absence of public funding of political parties; the fourth are the set of rules that allow a president to stand for re-election; and finally the rules that vest in the President huge and wide powers of appointment to public offices. To avert sliding into civil conflicts on accounts of competitive elections, and instead consolidate and sustain the country's democracy, it is imperative that the rules of governance are reordered in a manner that promotes nation-building, real good governance, and economic opportunities for all.

\section{References}

Abotsi, E. (2013). Rethinking the Winner-Takes-all System. IEA Governance Newsletter, 19(4), 1-8.

Anyimadu, A. (1997). Overdrawing the Nation: The National Question in the Political Theories of Ghanaiann Constitutions. In G. Nzongola-Ntalaja, \& M. C. Lee, The State and Democracy in Africa. Harare, Zimbabwe: African Association of Political Science .

Asante, K. (2016, August 15). What is the answer to 'Winner-takes-all politics'? Graphic. 
Bayart, J.-F. (1993). The State of Politics in Africa: Politics of the Belly. New York and London: Longman.

Bearfield, D. A. (2009). What Is Patronage? A Critical Reexamination. Public Administration Review, 69(1), pp. 64-76.

Campbell, J. L. (2004). Institutional Change and Globalization. Princeton, New Jersey : Princeton University Press.

Carey, J. M. (2013). The Reelection Debate in Latin America. Latin American Politics and Society, 45(1), 119133.

Chabal, P., \& Daloz , J.-P. (1999). 1999. Africa works: disorder as political instrument. London; Oxford: International African Institute in association with James Currey.

Clapham, C. (1985). Third World Politics: An Introduction. Lancaster : Routledge .

Commission Constitution Review. (2011). From a Political to a Developmental Constitution. Republic of Ghana, The Presidency . Ghana Publishing Corporation.

Downs, A. (1957). An Economic Theory of Democracy. New York: Harper and Row.

Fish, C. R. (1905). The Civil Service and the Patronage. New York, USA: Longmans, Green and Company.

Friedrich, C. J. (1937). The Rise and Decline of the Spoils Tradition. The Annals of the American Academy of Political and Social Science, 189, pp. 10-16.

Ghana News Agency. (2014, July 10). Winner-takes-all undermines development - IEA. Retrieved May 2020, from Ghananewsagency.org: https://www.ghananewsagency.org/social/winner-takes-all-underminesdevelopment-iea-77105http:/www.ghananewsagency.org/social/winner-takes-all-undermines-developmentiea-77105

Ghanaweb. (2017, June 21). The President has no business appointing IGP, Chief Justice - Emile Short. Retrieved May 2020, from ghanaweb.com: https://www.ghanaweb.com/GhanaHomePage/NewsArchive/The-President-has-no-business-appointingIGP-Chief-Justice-Emile-Short-550847

Ghanaweb. (2017, October 20). Winner takes all' is a threat to Ghana's development - Dr. Akwetey. Retrieved May 2020, from Ghanaweb.com: https:/www.ghanaweb.com/GhanaHomePage/NewsArchive/Winnertakes-all-is-a-threat-to-Ghana-s-development-Dr-Akwetey-592598

Ghanaweb. (2018, January 8). 4th Republic@25: Public corruption must end - CDD. Retrieved May 2020, from Ghanaweb.com: https://www.ghanaweb.com/GhanaHomePage/NewsArchive/4th-Republic-25-Publiccorruption-must-end-CDD-615295

Goodin, R., \& Jones, B. (1999). HERBERT A. SIMON: A Biographical Sketch. In Simon H., Arrow K., Buchanan J., Becker G., North D., \& Selten R. (Authors) \& Alt J., Levi M., \& Ostrom E. (Eds.), Competition and Cooperation: Conversations with Nobelists about Economics and Political Science (pp. 57-119). Russell Sage Foundation. Retrieved June 2, 2020, from www.jstor.org/stable/10.7758/9781610440042.7

Graphic. (2019, November 5). NDC accuses President Akufo-Addo of unprecedented nepotism. Retrieved May 2020, from graphic.com.gh: https://www.graphic.com.gh/news/politics/ndc-accuses-president-akufo-addoof-unprecedented-nepotism.html

Gyampo, R. (2015). Dealing with Ghana's Winner-Takes-All Politics: The Case for an Indepedent Parliament. IEA Governance Newsletter, 20(1), 1-13.

Gyampo, R. (2015). Winner-Takes-All Politics in Ghana: The Case for Effective Council of State. Journal of Politics \& Governance, 4(1-4), 17-24.

Gyimah-Boadi, E. (2003). Ghana : the political economy of 'successful' ethno-regional conflict management. In S. Bastian, \& R. Luckham, Can democracy be designed? : the politics of institutional choice in conflict-torn societies (pp. 120-144). London: New York: Zed Books.

Hall, P. (1986). Governing the Economy: The Politics of State Intervention in Britain and France. New York: Oxford University Press.

Hall, P., \& Taylor, R. (1996). Political Science and the Three New Institutionalisms. Political Studies, XLIV, 936-57.

Hofstadter, R. (1970). The Idea of a Party System: The Rise of Legitimate Opposition in the United States, 17801840. California, USA: University of California Press,

Ijon, F. (2018). Winner-Takes-All Politics and Democratic Consolidation in Ghana's Fourth Republic. Asian Research Journal of Arts \& Social Sciences, 7(4), 1-11.

Jackson, A. (1829, December 8). State of the Union (1829). Retrieved May 2020, from https://teachingamericanhistory.org/: $\quad$ https://teachingamericanhistory.org/library/document/state-of-theunion-address-39/

Joseph, R. (1987). Democracy and Prebendal Politics: The Rise and Fall of the Second Republic. : New York: Cambridge University Press.

Kelsall, T. (2011). Is it possible to boost poverty-reducing economicinvestment and growth in Africa by working 
with,rather than against, prevailing political-economicrealities? That is the question this article seeksto answer. Most African political economies, it iswell kno. IDS Bulletin, 42(2), 76-87.

Kpessa, M., \& Atuguba, R. (2013). Grounding with the People: Participatory Policy Making in the Context of Constitution review in Ghana. Journal of Politics and Law, 6(1), 99-110.

Krasner, S. D. (1982). Structural Causes and Regime Consequences: Regimes as Intervening Variables . International Organization, 36(2), 185-205.

Kumah-Abiwu, F. (2017). Issue framing and electoral violence in Ghana: a conceptual analysis. Commonwealth \& Comparative Politics, 55(2), 165-186.

Lamptey, A. A., \& Salihu, N. (2012). Interrogating the Relationship between the Politics of Patronage and Electoral Violence in Ghana. In K. Aning, \& K. Danso, Managing Elections Related Violence for Democratic Stability in Ghana. Accra: Friedrich-Ebert-Stiftung Ghana.

Lindberg, S. I. (2003). 'It's Our Time to "Chop"': Do Elections in Africa Feed Neo-Patrimonialism rather than Counter-Act It? Democratization, 10(2), 121-140.

Lindberg, S. I. (2003). 'It's Our Time to "Chop"': Do Elections in Africa Feed Neo-Patrimonialism rather than Counter-Act It? Journal of Democratization, 10(2), 121-140.

Mahama, J. (2012). Critical Policy Options of John Mahama Administration September to December 2012. Accra: Government of Ghana.

March, J. G., \& Olsen, J. P. (1984). The New Institutionalism: Organizational Factors in Political Life. The American Political Science Review, 78(3), 734-749.

McNamara, R. (2020, Febuary 11). The Spoils System: Definition and Summary. Retrieved May 2020, from www.thoughtco.com: https://www.thoughtco.com/the-spoils-system-1773347

Modernghana. (2009, Febuary 3). Mills Picks 75 Ministers. Retrieved May 2020, from modernghana.com: https://www.modernghana.com/news/204435/mills-picks-75-ministers.html

News Ghana. (2015, July 9). Palmer Buckle joins campaign against winner-takes all. Retrieved May 2020, from newsghana.com.gh: https://newsghana.com.gh/palmer-buckle-joins-campaign-against-winner-takes-all/

Nkansah, L. A. (2012, March 1). ransfer of Power to a New Administration in Ghana's Democratic System: The Way Forward. Retrieved May 2020, from https://papers.ssrn.com: https://papers.ssrn.com/sol3/papers.cfm?abstract_id=2014000\&download=yes

North, D. (1990). Institutions, Institutional Change and Economic Performance. Cambridge: Cambridge University Press.

O'Donnell, G. (1996). Illusions about consolidation. Journal of Democracy, 7(2), 34-51.

Ostrom, E. (1986). An Agenda for the Study of Institutions. Public Choice, 48, 3-25.

Peters, G. (1999). Institutional Theory in Political Science: The New Institutionalism. London: New York: Pinter. Sandrook, R. (1985). The Politics of Africa's Economic Stagnation. Cambridge : CambridgeUniversity Press.

Scott, J. C. (1972). Patron-Client Politics and Political Change in Southeast Asia. The American Political Science Review, 66(1), 91-113.

Somit, A. (1984). Andrew Jackson as Administrator. Public Administration Review, 8(3), pp. 188-196.

Van de Walle, N. (2001). Political Economy of Institutions and Decisions. New York: Cambridge University Press.

Van de walle, N. (2007). Meet the new boss, same as the old boss? The evolution of political clientelism in Africa. In H. Kitschelt, \& S. I. Wilkinson, Patrons, Clients, and Policies Patterns of Democratic Accountability and Political Competition (pp. 50-67). New York: Cambridge : Cambridge University Press.

Weber, M. (1947). The Theory of Social and EconomicOrganization, London: . London: William Hodge andCompany Ltd. 